Open Access

\title{
Dynamics of EU food safety certification: a survival analysis of firm decisions
}

\author{
Catherine Ragasa ${ }^{1 *}$, Suzanne Thornsbury ${ }^{2}$ and Satish Joshi ${ }^{3}$
}

\author{
* Correspondence: \\ C.Ragasa@cgiar.org \\ ${ }^{1}$ Development Strategy and \\ Governance Division of \\ International Food Policy Research \\ Institute, Washington, DC, USA \\ Full list of author information is \\ available at the end of the article
}

\begin{abstract}
The article empirically examines the timing of initial decisions to adopt food safety systems and subsequent decisions to maintain the certification. Survival models are used to evaluate firm-level decisions among seafood processors in the Philippines. Whereas initial certification decisions were influenced mainly by easily obtainable a priori indicators such as output price, scale of production, and association membership, decisions to continue certification were influenced by a larger number of less-visible factors including price differentials across markets and cost structures. Managerial hubris may have played a role in initial certification decisions, but decertification decisions were more informed by realized cost-benefit comparisons. Results highlight tendencies to initially overestimate of benefits and underestimate costs of food safety certifications, resulting in unrealistically optimistic projections and may lead to adverse firm performance.
\end{abstract}

Keywords: HACCP, Food safety, Survival analysis, Seafood industry

JEL classification: Q18, Q13, D22, L66

\section{Background}

The importance of achieving and maintaining food safety has never been more apparent. High-profile outbreaks and rising consumer concerns increase pressure on public and private decision makers to identify and resolve systemic problems. Numerous studies have focused on the adoption of certification and management systems (privately or publicly managed) as a way to improve food safety performance and as an important component of food trade policy (Curzi et al. 2015; Hammoudi et al. 2009; Menard and Valceschini 2005; Henson and Caswell 1999). A particular focus has been the Hazard Analysis and Critical Control Points (HACCP) system-one of the more widely used methods of food safety management, a process standard recommended by the Codex Alimentarius Commission of the Food and Agriculture Organization of the United Nations and the World Health Organization, and a required system in the European Union (EU) and the USA. HACCP has been proven to reduce foodborne illness and is critical for public health (Minor and Parrett 2017; Unnevehr 2015).

There are also major implications of HACCP and other food safety standards on international trade (Maldonado-Siman et al. 2014; Handschuch et al. 2013; Anders and Caswell 2009). In general, HACCP compliance is costly at the start and especially taxing to poor countries and small firms with limited technical capacity and resources

(c) The Author(s). 2017 Open Access This article is distributed under the terms of the Creative Commons Attribution 4.0 International License (http://creativecommons.org/licenses/by/4.0/), which permits unrestricted use, distribution, and reproduction in any medium, provided you give appropriate credit to the original author(s) and the source, provide a link to the Creative Commons license, and indicate if changes were made. 
(Anders and Caswell 2009; Ragasa et al. 2011a), but once HACCP compliant, firms' access to international markets opens up (Handschuch et al. 2013). In the Philippines, compared to 1990-1997 (pre-HACCP) levels, the value of Philippines exports to EU declined by $9 \%$ in 1998-1999 and by 23\% in 2000-2004 (Department of Trade and Industry (DTI), 2006), but once the country and firms gained experience and were able to adjust, the country's exports jumped to high levels starting in 2007-2008, increasing by an average of 33\% annually (Israel 2014). While the number of EU certified were less in 2015-2016 than in 2005-2006 levels, the jump on seafood exports signal substantial expansion in production of relatively smaller number of seafood processing firms.

Despite these benefits, it is not clear why HACCP adoption remains low and why some firms decertify or discontinue their certification at some stage. Some studies have suggested that food producers and processors do not always embrace HACCP with the anticipated enthusiasm (Maldonado-Siman et al. 2014; Taylor and Taylor 2004; Panisello and Quantick 2001). There is growing number of studies detailing the costs of HACCP compliance (Maldonado-Siman et al. 2014; Handschuch et al. 2013; Ragasa et al. 2011b). Prior literature has identified a number of factors that affect initial adoption of HACCP, including length of time to develop and implement the program, technical expertise and support, availability of human resources, production technology and design, company size, and level of institutional support (Wallace et al. 2014; Dzwolak 2014; Green and Kane 2014; Fotopoulos and Kafetzopoulos 2011). In addition, institutional theorists have identified social acceptability, credibility, and legitimacy as important drivers of firms' choices to adopt HACCP (Meyer and Rowan 1977; Scott 2001; Bansal and Clelland 2004). From international trade perspective, HACCP adoption is proven to be complex and depends on a variety of factors including exporting country characteristics, value of trade, target market, type of regulations, extent of implementation, and commodity types (Handschuch et al. 2013; Ragasa et al. 2011a).

Further, there are indications of the dynamics of participation (entry, exit, and re-entry) in these certification systems; for example, more than $60 \%$ of certified firms in the seafood industry in the Philippines have discontinued EU HACCP certification in 2006 and another episode of delistings in 2010 and a minor one in 2015 (Fig. 1). The lack of understanding about such decertifications is a major knowledge gap in food safety policy. The Philippine case is also interesting not only because it is a major player in the international seafood trade but also because of the large number of firms that discontinued their EU HACCP certification over time, suggesting that there may have been significant ex ante mis-estimation of HACCP costs implying managerial hubris and possibly leading to adverse firm performance.

In this article, we analyze the factors that explain this dynamics of participation or certification in this HACCP system (i.e., initial decisions to adopt food safety systems and subsequent decisions to maintain the certification and the timing of these decisions). Figure 2 shows the dynamic process, in which a firm has to decide whether to have HACCP certification or not in a yearly basis starting from years before 1999, when the mandatory regulation on all seafood suppliers in USA and EU was implemented. Due to the multi-period investments required, the decision to adopt occurs prior to the period when the actual adoption is undertaken or observed. Two main categories of firms are apparent from the observed adoption of HACCP systems as shown in Fig. 2: (i) firms that were certified at least once (represented by the darker solid arrows) and 


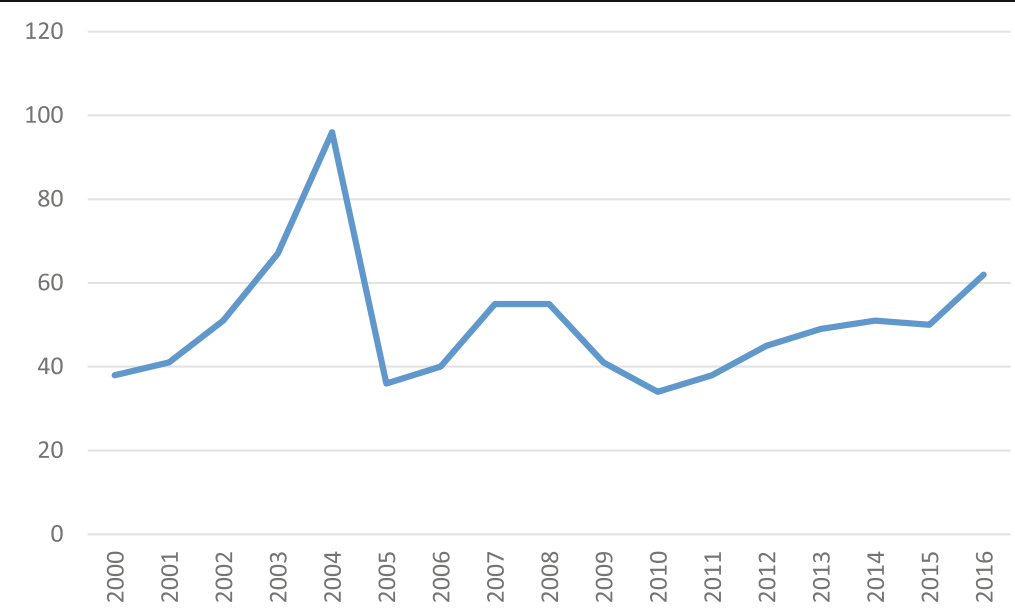

Fig. 1 Number of fisheries processing plants certified with EU HAACP. Source: Various BFAR records, both paper-based and online (accessed on March 3 2005; November 20 2007; March 2 2017) for most of 20002016, except on the following years: 2008-2009: http://eeas.europa.eu/archives/delegations/philippines/documents/more_info/newsletters/mar09_en.pdf (accessed on March 2 2017); 2010: http://edz.bib.uni-mannheim.de/daten/edz-a/gdgv/11/2011-8896_FINAL.pdf (accessed on March 2 2017)

(ii) firms that were never certified (represented by the lighter solid arrows). Within the first category are firms that are "certified" (represented by darker solid arrows) and "decertified" as of 2006 or in another years after that (represented by the lighter broken arrows). In addition, firms that were certified at least once have different years of initial adoption, and this imply varying rates of initial adoption.

The contribution of this paper is fourfolds. First, the dynamics of HACCP or other food certification is rarely studied, and we aim to address this knowledge gap. Second, we use an innovative approach, using survival models, and applied this to study the dynamics of food safety certifications. Survival analysis is used to assess longevity or duration where there are subjects who do not experience the event of interest at alternative points in time (Menard 2008; Singer and Willett 2003). It has been widely used in epidemiology and medical research to explain occurrence of and survival from a disease (for example, Kurian et al. 2009; Song and Lawson 2009; Spitale et al. 2009; Madan et al. 2008). Application to economic

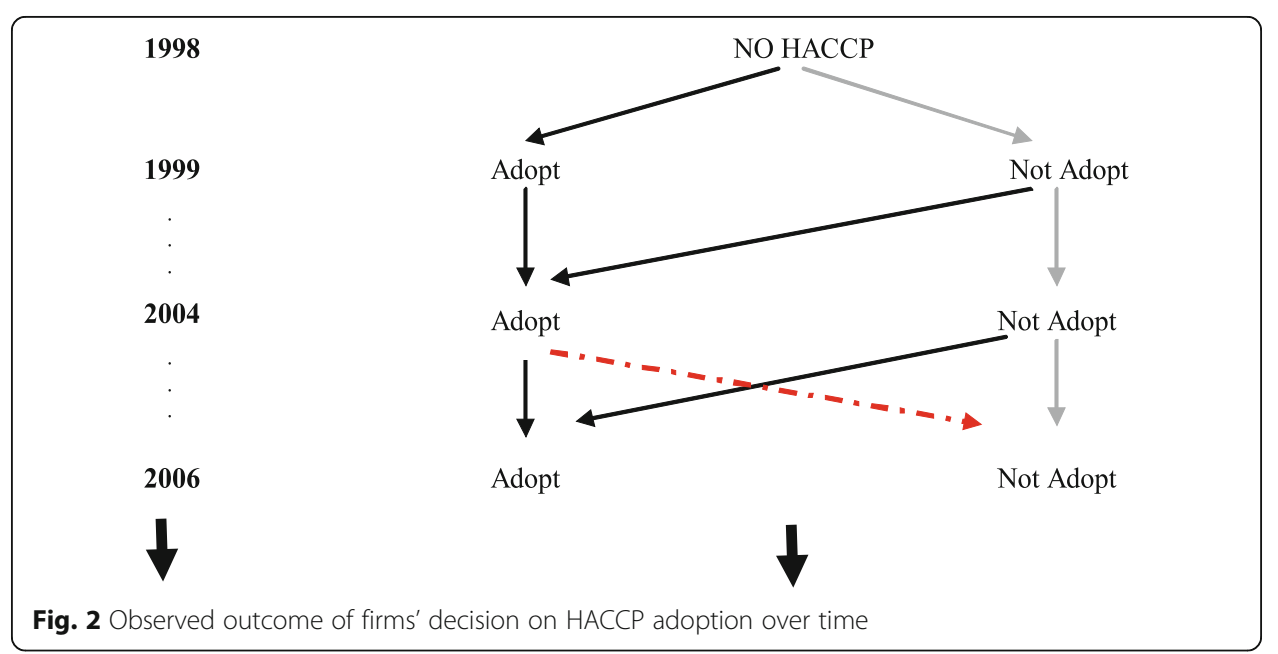


problems is less frequent but targeted to issues where length of time or time periods is the focus-that is, exit or survival of firms (Olmos 2010; Tiller et al. 2009; Dimara et al. 2008; Soderbom et al. 2006); rate of technology adoption (Abdulai and Huffman 2005); rate of contract termination (Olmos 2010); length of visitor stay (Barros and Machado 2010); timing of loan default (Roszbach 2004); infrastructure failure (Debon et al. 2010); and employee retention (Mattox II and Jinkerson 2005).

In the case of food safety, a subset of firms initially adopt EU HACCP systems; some of which maintain their certification and some of which subsequently decertify (Fig. 2), which makes survival analysis an appropriate tool to evaluate the time-path of food safety certification. Earlier studies do not explicitly address the effect of factors on the time-path of adoption or certification (Abdulai and Huffman 2005). Although some prior studies have analyzed factors affecting food safety controls, including HACCP, using discrete choice models such as logit and probit (Herath et al. 2007; Henson and Holt 2000), to the best of our knowledge, this study is the first to apply survival or hazard functions to food safety certification decisions.

Third, empirical analysis of food safety issue applied to developing countries, with limited resources and higher trade-offs between food safety and other investments, is limited. In particular, firm-level research in developing countries is limited to a few qualitative case studies, and we aim to add to the relatively few quantitative analyses on this issue. This paper aims to contribute to the knowledge gap on the factors affecting the dynamics of HACCP certification specifically and on the implications of food safety standards to developing countries' trade and welfare more generally.

\section{Literature review and framework}

The literature on food safety points to both incentives and capacity as the broad factors that explain food safety certification. The main theory and concept used is standard microeconomics, in which the guiding principle is profit maximization. Given a certain production function, firms make choices and weigh the costs versus the benefits derived from adoption, including the opportunity costs associated with non- or discontinued adoption and those derived from continued adoption. We also utilized other concepts to explain the factors affecting HACCP certification including social capital, networking, and partnerships within institutional economics and the concept of managerial hubris reflecting asymmetric or incomplete information or overconfidence or risk-taking behavior within the strategic management literature

\section{Profit maximization}

Following Rosen's (1974) model of a competitive industry with product differentiation, ${ }^{1}$ let product demand be described by the function:

$$
Y^{d}=f(P, S, Q, Z)
$$

where $P$ is the price of $Y, S$ is the level of food safety, $Q$ is the vector of product quality attributes other than food safety, and $Z$ is the vector of other demand variables. Market supply is given by the function: 


$$
Y^{s}=f(P, S, \boldsymbol{Q}, \boldsymbol{W}, \boldsymbol{K}),
$$

where $W$ is the vector of factor prices, $K$ is the vector of other supply variables, and other variables remain as defined above. Equating demand and supply and solving for $S$ yield the function:

$$
S=F\left(\boldsymbol{Q}, P^{*}, \boldsymbol{W}, \boldsymbol{K}, \boldsymbol{Z}\right),
$$

where $P^{*}$ now is the equilibrium price of $Y . P^{*}$ can be decomposed into $P_{Y}$ and $P_{S}$, where $P_{Y}$ is the price level of product sold and $P_{S}$ is the price of $S$. However, measuring $P_{S}$ is not straightforward. One way of putting a value to $P_{S}$ is by measuring the cost of food safety systems and using this as an approximation of $P_{S}$. When looking at the part of $P^{*}$ that is attributable of $S$, one can use the output price differential between buyers who are willing to accept safer products and those who accept products that are less safe. For instance, we assume buyer 1 demands safer products $\left(S_{1}\right)$ and pays $p_{1}$ and buyer 2 who accepts less safe products $\left(S_{2}\right)$ pays $p_{2}$. The price differential of these two buyers is $\left(p_{1}-p_{2}\right)$, equated as the price of $\left(S_{1}-S_{2}\right)$. This is not the same as $P_{S}$ per se, but will be relevant in later discussion of factors affecting firm choice of the level of $S$.

With HACCP systems $(H)$ as an internationally known system for attaining food safety, $H$ enters through $K$ and as $Z$ in $S . H$ is not exogenous, and its adoption is determined by both supply- and demand-related factors. Both $S$ and $H$ are simultaneously estimated as given in Eqs. 4 and 5 below:

$$
\begin{aligned}
& S=F\left(\boldsymbol{Q}, P_{Y}, P_{S}, \boldsymbol{W}, \boldsymbol{K}, \boldsymbol{Z}, H\right) \\
& H=F\left(S, \boldsymbol{Q}, P_{Y}, P_{S}, \boldsymbol{W}, \boldsymbol{K}, \boldsymbol{Z}\right)
\end{aligned}
$$

Individual firms will maximize profit $(\pi)$ by choosing $S$ and $H$ given by the Eq. 6 below:

$$
\operatorname{Max} \pi=P^{*}(S, H) . Y(S, H)-C(S, H)
$$

where $C$ is the total costs and other variables are as defined above. Once $S$ and $H$ are chosen, firms will choose the combination of $Y$, which is the output level, and $X$, which is the vector of input levels. From an empirical perspective, the difficulty arises due to the unobservability of $S$. Antle (2000) included observed "product quality," using a measure of management intensity and proportion of processed product in total product, as proxy variables for the unobserved food safety in analyzing the cost of HACCP systems in the US meat industry. Ollinger et al. (2005) studied process control and sanitation compliance and used microbial count and/or defects of intermediate and final products in the US meat industry as measures of food safety (or its absence). However, even these types of data are often nonexistent in many countries. To overcome this lack of observability of $S$ and difficulty of measuring $Q$, we assume that $H$ is a proxy for $S$ and $Q$. Thus, instead of solving for Eqs. 4 and 5, we estimate Eq. 7 below:

$$
H=F\left(P_{Y}, P_{S}, \boldsymbol{W}, \boldsymbol{K}, \boldsymbol{Z}\right)
$$

The reduced form of Eq. 7 is where HACCP certification decision by a firm in a given year is the price of output $P_{Y}$; factor prices, $W$, which affect the overall cost of production and complying with HACCP (therefore also $P_{S}$ ); indicators of alternative markets or opportunities that do not require HACCP certification equivalent 
to that for the EU market including price differences between EU and US markets, price differences between EU and other markets, number of markets, and number of product forms are demand shifters used $(\boldsymbol{Z})$; and firm capacity indicators such as operation size, access to resources and social capital, experience, and condition of the processing plant are used as supply shifters $(\boldsymbol{K})$. The actual variables used and their definitions and the hypotheses tested are shown in Table 1.

\section{Social capital}

Social capital, ${ }^{2}$ networking, and partnership have drawn much attention in the literature. Social capital among firms, especially among smaller ones, is important for resource mobilization and knowledge sharing (Russo and Perrini 2010; Cooke and Wills 1999). Cooke and Wills (1999) show that in sizeable proportion of firms in Denmark, Ireland, and Wales (UK), social capital building was associated with enhanced business, knowledge, and innovation performance. There is also growing body of literature on social capital and its role in transparency and coordination in food systems (Trienekens et al. 2012; Sporleder and Moss 2002; Jarosz 2000; Ziggers and Trienekens 1999). Most of the latter discuss about vertical coordination, while a few studies talk about social capital or networks used for quality signaling and about horizontal coordination and networking to pool resources and knowledge. Several studies show about greater access to credit and resources for those members of association, organization, or trade group. Especially for smaller firms, these technical knowhow and resources are more limiting, and networks and linkages with other organizations may prove to be very useful for these firms to adopt and continue certification of their production. We hypothesize that social capital, measured in terms of firm's membership in associations and trade groups, increases the likelihood of HACCP certification and the rate of this certification.

\section{Strategic management}

After initial certification, a firm's decision to continue with, or discontinue, the certification at any point in time will be influenced by the same set of incentive- and capacity-related factors, but now with additional information on realized costs and outcomes. Firms with the necessary capacity to implement the program successfully and subsequently realize the expected net benefits from HACCP certification will continue with their programs, but firms that lack capacity or fail to realize the projected net benefits may seek decertification. Failure to realize anticipated benefits may be the result of ex ante unrealistically optimistic projections (that is, managerial hubris) or subsequent changes in markets and external conditions. Literature in strategic management identifies managerial hubris as a major cause of adverse firm performance, especially in explaining the failure of major strategic moves, such as mergers and acquisitions, or decreases in firm profitability (Roll 1986; Jiang et al. 2011). Other studies suggest that firms often misestimate costs of regulations including those for food safety (Joshi et al. 2001; Morgenstern et al. 2001; Ragasa et al. 2011b.

Prior to certification, the actual costs and benefits to a firm are not known. Uncertainty can be reduced through ex ante information collection and assessment but cannot be entirely eliminated. Once certification is undertaken and outcomes are realized, 


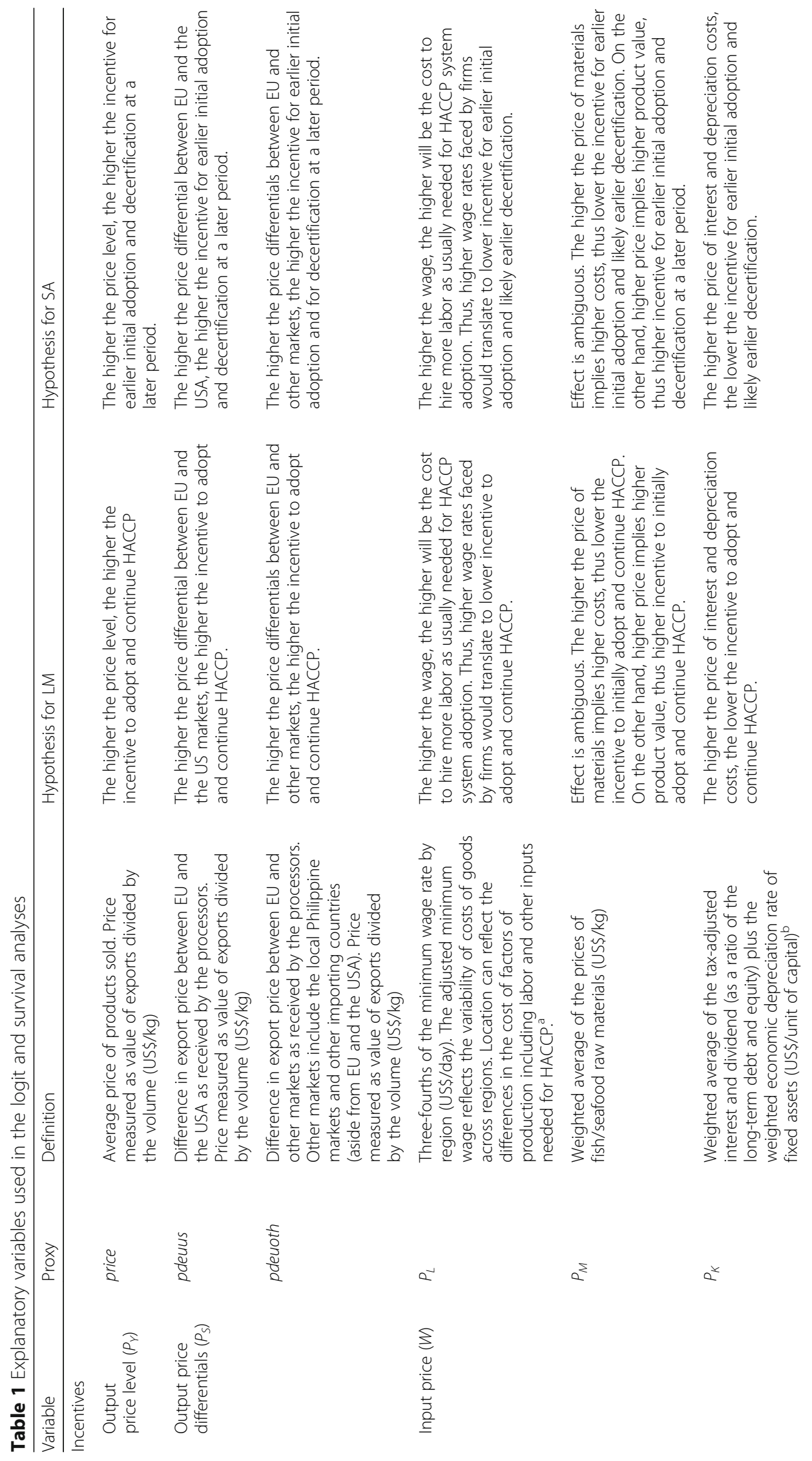




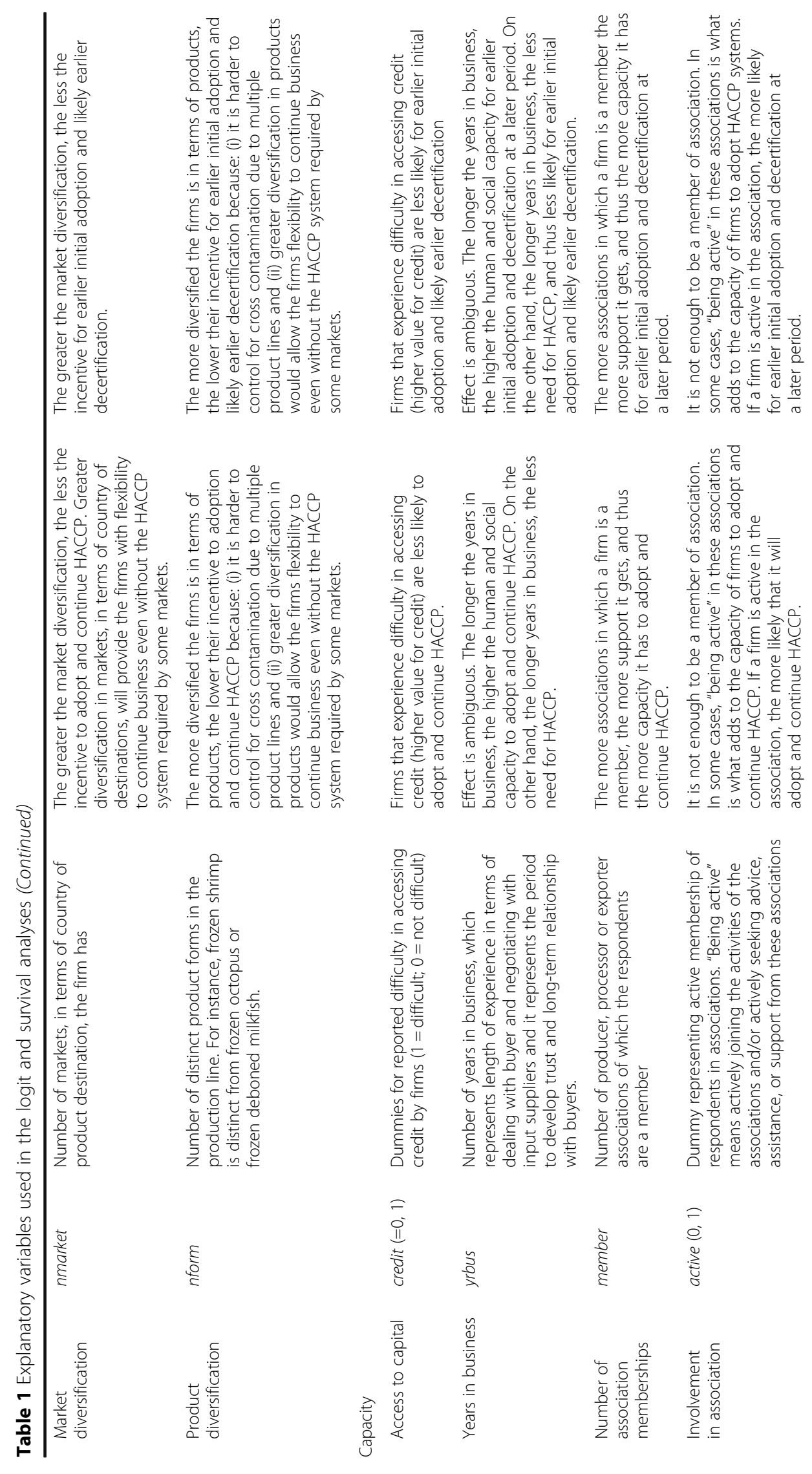




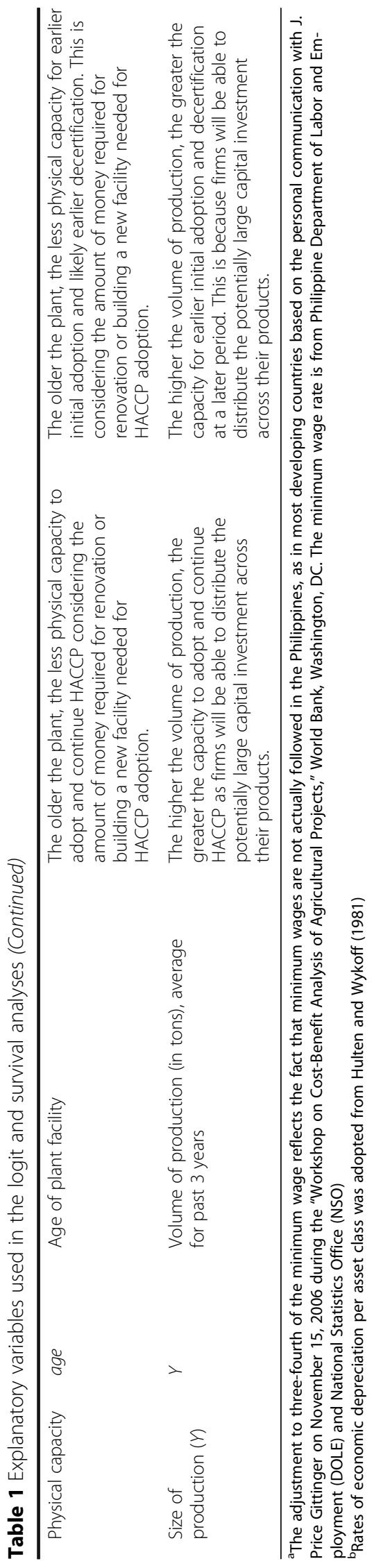


firms have additional information and investments that will influence subsequent decisions about sustainability. The difference between anticipated and realized outcomes is known only over time and will vary across firms. We hypothesize that the time duration before a firm gets certified depends on the strength of incentive (that is, expected net benefits) and capacity factors (that is, firm capacity for implementation or early adoption). We hypothesize that conditional on initial certification, the period for which a firm remains certified (that is, does not get decertified) is positively associated with the strength of incentive and capacity factors. We expect the ex post decisions over decertification to be more strongly associated with incentive and capacity than the ex ante decisions about initial certification, because decertification decisions are likely based on known information in contrast to projections and managerial hubris.

\section{Methods}

\section{Data and variables}

This article focuses on Philippine seafood processing firms to meet EU HACCP certification requirements. We define HACCP-certified firms as those which are certified by BFAR for export to EU, regardless of their export status with respect to other countries. ${ }^{3}$

Firm-level data were collected from 59 seafood processors located in the Luzon, Visayas, and Mindanao cluster areas in the Philippines. ${ }^{4}$ Face-to-face interviews using a semistructured questionnaire were conducted in September to December 2005 with plant managers to collect data covering the period 1998 to 2005 of their operations. A visit of a random selection of these processors was made in 2011 and in 2014. The sample includes a variety of firm sizes (15 cottage or microscale, 14 very small, 6 small, 15 medium, and 9 large) and product categories (17 frozen tuna processors, 10 milkfish, 9 shrimp, 8 canned tuna, and 15 other products). ${ }^{5}$ Respondents included 41 firms that initially received EU HACCP certification, 15 of which were subsequently decertified. ${ }^{6}$ The remaining 18 firms in the sample never received EU HACCP certification. ${ }^{7}$

The timing of initial adoption and the duration of certification varied across the sample firms (Table 2). Table 1 shows incentive- and capacity-related explanatory variables and their hypothesized relationship with initial and continued adoption decisions consistent with variables described in Eq. 7 and on social capital. Incentives include expected or perceived net benefits, both financial and nonfinancial, from adopting HACCP standards. Financial variables include average price received for products sold (output price level or $P_{Y}$ ) and difference in export price between EU and other markets (output price differential or $P_{S}$ ). These are the output prices reportedly received by the processors interviewed. Estimated prices for labor $\left(P_{L}\right)$, materials $\left(P_{M}\right)$, and capital $\left(P_{K}\right)$ are used as indicators of firm-level input cost structure that are exogenous in the model. Data on prices of inputs were sourced from the firm-level interviews and from the firms' financial and income statements from the Philippine Securities and Exchange Commission. Since higher revenues increase the likelihood of higher benefits from certification, we hypothesize that both the output price level and output price differential variables will be positively associated with initial certification but negatively associated with the decertification decision. As HACCP certification involves additional capital and operational investments and higher input prices adversely affect incremental 


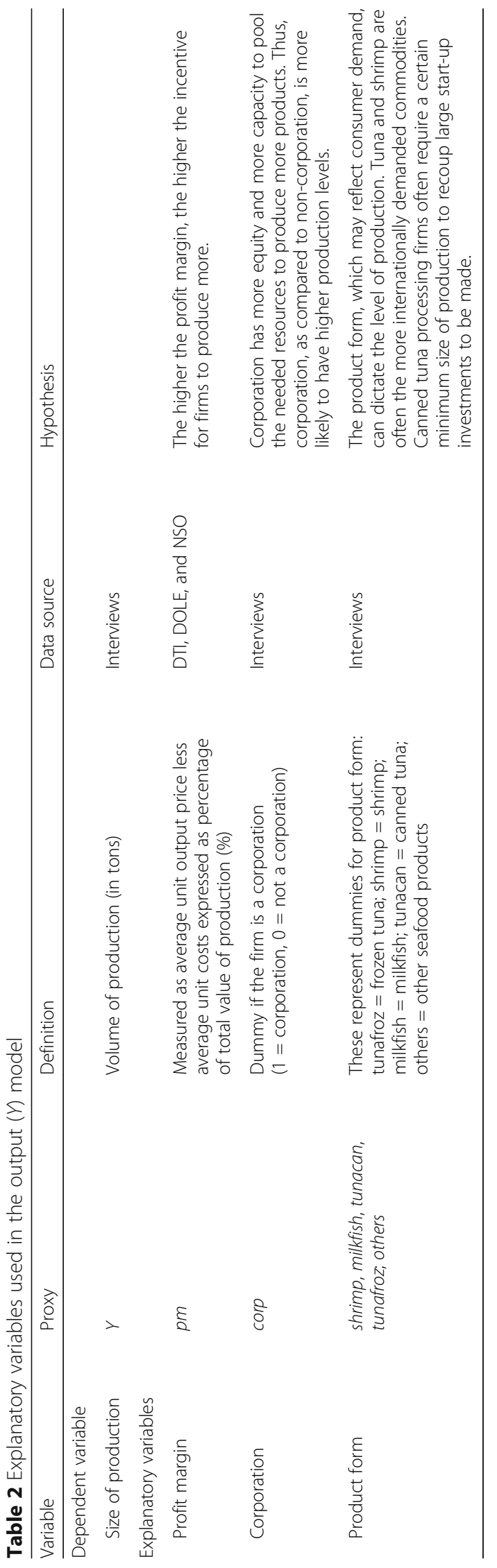


benefits from certification, we expect input prices $\left(P_{L}, P_{M}\right.$, and $\left.P_{K}\right)$ to be negatively associated with initial certification decisions but positively associated with subsequent decertification decisions.

Nonfinancial incentives include diversification, measured by both the number of markets in which the firm sells in terms of country of product destination (nmarket) and the number of distinct product forms that the firm processes in its production line (nform), and volume of output $(Y)$ as a measure of size. Greater diversification, both in terms of geographical area and the number of products, gives the firm flexibility to continue business even without HACCP certification, thereby reducing its incentives to seek HACCP certification. Hence, we hypothesize that both market diversification (nmarket) and product diversification (nform) will be negatively associated with initial certification but positively associated with decertification decisions. Because of significant fixed costs associated with HACCP certification, we expect economies of scale in realizing benefits from certification and hypothesize a positive association between volume of production and initial certification and a negative association with subsequent decertification decisions. Rouviere (2016) explores the relationship between US and UK food firms' size and their level of prevention efforts and shows that when cross-contamination between units is unlikely, small firms undertake greater prevention efforts than large firms. But when cross-contamination between units is possible, the effort-size curve is an inverted $U$ shape.

Capacity variables focus on the financial, human, and institutional resources to set up and manage HACCP systems. A dummy variable credit represents difficulty in accessing credit in addition to the more direct measure of price of capital $\left(P_{K}\right)$. Number of years in business (yrbus) is a proxy for operational experience and human capital. We hypothesize that a firm with higher difficulty in accessing capital, higher price of capital, and fewer years in business (that is, low operational capacity) has a lower probability of achieving initial HACCP certification and a higher probability of being subsequently decertified. We include age of the plant (age) in our estimations, and as older plants are likely to need higher investments in upgrading to meet HACCP standards, we hypothesize a negative association with the initial certification decision.

Variables used as measures of institutional support include the number of association memberships (member) and whether the firm was actively involved in such associations (active). These variables can be viewed either as proxy measures for the degree of external institutional pressures faced by the firm or as additional firm capacity because active membership provides the firm with access to resources, know-how, and potentially experienced manpower. We hypothesize a positive relationship between these variables and the likelihood of a firm receiving initial HACCP certification and a negative association with its subsequent decertification.

\section{Estimation methods: logit models and survival analysis}

Logit modeling and survival analysis are used to identify significant incentive- and capacity-related factors explaining behavior of firms toward initial adoption, speed of this adoption, continued certification, and the length of time between certification and decertification. Logit models are commonly used for binary outcomes and 
will not be explained in detail here (see Wooldridge 2003 for details). Instead, we focus below on survival analysis, which is a newer and rarely used modeling technique.

Survival analysis (also called duration or hazard analysis) is used to explain the intertemporal nature of firm action (Hosmer and Stanley 1999; Clarke et al. 2003; Wooldridge 2003). We use simple means comparisons between certified and decertified firms and logit model results, as benchmarks for comparison with survival model results. The first logit model analyzes the likelihood that a firm initially adopts EU HACCP at any point between 1998 and 2005. A second logit model analyzes the likelihood that a certified firm is decertified at any point during the period. These two models assume that the probability of an event occurring in period $t$ is independent of time before the event occurs (constant-hazard-rate assumption), but one can hypothesize that the longer the time period over which a firm has operated without HACCP, the higher the likelihood that it will not adopt HACCP in the next period. Similarly, it is likely that the longer a firm remains certified, the greater the likelihood that this firm will not be decertified in the next period.

For initial adoption, the survival time is the number of years before a firm adopts HACCP after the year the EU markets imposed the system (that is, 1999) (Table 2[a]). For decertification decisions, survival time is the number of years between initial certification and the year that a firm is decertified (Table 2[b]). The distribution of survival time can be characterized by three equivalent functions: the density function, the survivor function, and the hazard function. The density function is

$$
f(t)=\operatorname{Pr}\left(T=t_{i}\right)
$$

where $T$ is a nonnegative random variable that takes values $t$ to measure the time spent in a particular state. The survivor function is defined as the probability that the event of interest has not occurred by duration $t$-that is, the random variable $T$ exceeds (or at least equals) the specified time $t$. For the discrete case, it is given by

$$
S(t)=\operatorname{Pr}\left(T \geq t_{i}\right)=\sum_{j \geq i} f\left(t_{j}\right)
$$

where $j$ denotes a failure time. $S(t)$ is a nonincreasing function with a value of one at the time origin and a value of zero as $t$ goes to infinity.

The opposite of the survivor function, the hazard function, is the relationship between the hazard rate and the time already spent in that state and is presented as

$$
h\left(t_{i}\right)=f\left(t_{i}\right) / S\left(t_{i}\right)
$$

The hazard function represents the conditional probability of an event occurring at the next time point, given that the event has not occurred up to a previous point. Estimation in this article employs the hazard function.

Hazard functions can be estimated using either semiparametric or parametric methods. ${ }^{8}$ Semiparametric models are more appealing as they allow greater flexibility; in semiparametric models, the baseline hazard $\lambda_{0}(t)$ is left unspecified. ${ }^{9}$ Hazard is a 
function of a vector of explanatory variables $X$ with coefficients $\beta$ that can be estimated. The baseline hazard $\lambda_{O}$ is given as

$$
h\left(t, x, \beta, h_{0}\right)=h_{0}(t) \phi(X, \boldsymbol{\beta})
$$

where $\phi$ is a positive function of $X$ and $\beta$ and $h_{0}(t)$ characterizes how hazard changes as a function of time. The baseline hazard depends on $t$, but not on $X$, meaning that it captures individual heterogeneity unexplained by the explanatory variables. Alternatively, the baseline hazard can be interpreted as the probability of an event occurring if the explanatory variables are set equal to zero.

We adopt the semiparametric procedure developed by Cox (1972), where $\phi(X, \beta)$ is equated with exponentiated $(X, \beta)$ given as

$$
\phi(\boldsymbol{X}, \boldsymbol{\beta})=\exp (\boldsymbol{X}, \boldsymbol{\beta})
$$

To estimate the hazard function, observed time periods of the event occurring are ordered by length from smallest to largest, $t_{1}<\ldots<t_{n}$. The conditional probability that the event happens in the first observation at time $t_{1}$, given that any of the $n$ observations could have been failed at $t_{1}$, is

$$
\frac{\exp \left(x_{1}, \beta\right)}{\sum_{i-1}^{n} \exp \left(x_{i}, \beta\right)}
$$

or the contribution of the shortest observation to the partial likelihood. More generally, the contribution of the $j$ th shortest observation to the partial likelihood is given by

$$
\frac{\exp \left(x_{j}, \beta\right)}{\sum_{i-j}^{n} \exp \left(x_{i}, \beta\right)}
$$

For HACCP adoption, the numerator is the conditional probability of the jth firm that initially adopts (or decertifies) at time $t_{j}$, whereas the denominator is the sum of the partial likelihood for all other firms that have not initially adopted (or that have not been decertified) just prior to time $t_{j}$. The likelihood is formed as the product of these contributions and may be written as

$$
L(\beta)=\prod_{i-1}^{n} \frac{\exp \left(x_{j}, \beta\right)}{\sum_{i-j}^{n} \exp \left(x_{i}, \beta\right)}
$$

The likelihood function depends only on the unknown coefficient vector $\beta$ and can be maximized using standard methods. The functional form of the hazard rate does not need to be specified. The Cox log-likelihood function is then as follows:

$$
\ln L(\beta)=\sum_{i-1}^{n}\left\{\ln \phi\left(x_{i}, \beta-\ln \left[\sum_{j-i}^{n} \phi\left(x_{j}, \beta\right)\right]\right\}\right.
$$

where $\phi\left(x_{i}, \beta\right)=\exp \left(x_{i}, \beta\right)$. Explanatory variables, $x_{i}$ and $x_{j}$, are defined in Table 1 . The hazard ratio $(H R)$, which is $\exp (\beta)$, is the change in the rate of the event occurring for every unit change in the explanatory variable $X_{i}{ }^{10}$ For a dichotomous explanatory 
variable, the difference in the rate of $X_{i}=1$ and $X_{i}=0$ is equal to $H R$. An $H R$ greater than one $(H R>1)$ increases the rate of the occurrence of an outcome by $100 *(H R-1)$ percent; an $H R$ that is less than one $(H R<1)$ decreases the rate of an event occurring by $100 \% / H R-1 /$ percent.

\section{Endogeneity}

An econometric concern is the potential endogeneity of the explanatory variables. For instance, the size of production $(Y)$ can be a simultaneous decision factor along with the level or speed of HACCP adoption. Size of production can affect a firm's decisions about whether or not to adopt and when to adopt. At the same time, decisions about HACCP adoption may also affect the size of production through market access.

To handle the endogeneity problem in the models described above, a two-stage regression is estimated. The $Y$ model is based on a simple production function, where quantity of production is expressed as a function of output prices, input prices, and other firm characteristics. Due to the high correlation of most of the input prices with output price per unit, which is computed based on a formula of profit margin allowance on top of the input prices, profit margins $(\mathrm{pm})$ were used as an explanatory variable for output in this model instead of distinct output and input prices. In addition, other firm-specific factors are included in the model, such as a dummy for corporation (corp), as a proxy for capital availability; and dummies for product form (shrimp, milkfish, tunacan, tunafroz) as shown below

Table 3 Distribution of respondents based on year of initial adoption (a) and length of time before decertification (b) (reference is 2006)

\begin{tabular}{ll}
\hline (a) Initial adoption & Number of respondents \\
Length of time before initial adoption since 1999 & 7 \\
7 & 0 \\
6 & 5 \\
5 & 8 \\
4 & 6 \\
3 & 8 \\
2 & 1 \\
1 & 6 \\
0 & 18 \\
Have not certified & \\
(b) Decertification & \\
Length of time before decertification since initial adoption & Number of respondents \\
6 & 2 \\
5 & 1 \\
4 & 4 \\
3 & 4 \\
2 & 4 \\
Have not decertified & 4 \\
\hline
\end{tabular}




$$
\ln Y=\beta_{o}+\beta_{1} \text { pm }+\beta_{2} \text { corp }+\beta_{3} \text { shrimp }+\beta_{4} \text { milkfish }+
$$

Table 3 shows the definition of these variables and hypothesized relationship with $Y$. Intuitively, there is no reason to believe that these instruments can directly affect the dependent variable (initial or continued adoption), beyond their indirect effect through output. Formal tests were conducted to ascertain the validity of the instruments. The minimum condition for these instruments to be valid is that they are sufficiently correlated with the endogenous variables (Verbeek 2004, 148). This can be tested by estimating the first stage regression of each endogenous variable on the instruments used and performing an F-statistic test (Verbeek 2004, 145). Stock and Watson (2003), also cited in Verbeek $(2004,148)$, suggest that a minimum $F$-statistics of 10 is sufficient for validity. The $F$-statistic test results $(=11.01)$ confirm that the instruments used are strongly correlated with the endogenous variables instrumented. Predicted $Y$ (yhat) is an explanatory variable in the second-stage survival estimation to generate unbiased and robust estimates.

The Durbin-Wu-Hausman test was also performed for a possible endogeneity problem associated with association membership in the HACCP initial participation model. For example, the decision to join an industry organization could be influenced by the participation in HACCP. However, the test indicated no endogeneity issue.

\section{Results and Discussions}

\section{Initial adoption decisions}

Results are shown in Tables 4 and 5. Fit of the models is considered acceptable. Pseudo $R$ squared are 0.36 and 0.29 ; and the percentage of values correctly predicted are $60 \%$, and $55 \%$ are relatively fine for the logit models. For the survival models, 32 and $29 \%$ of absolute martingale residual deviation can be explained by the model, and these indicators are relatively fine indicating good model fit.

The baseline results in Table 4, without consideration of the timing of decisions, indicate that output price and quantity are positively associated with the initial decision by seafood processors to adopt HACCP. A higher output price received provides more incentive to adopt, and estimates suggest that a US\$1 increase in output price level is associated with a $32 \%$ increase in the likelihood of being certified at least once. A larger output (or firm size) allows the firm to capture some economies of scale and creates an incentive for certification. A means comparison indicates a significant difference between the average output of firms that initially adopt HACCP and those that do not.

Regression estimates suggest that a 1000-ton increase in annual output is associated with a $9 \%$ increase in the likelihood of being certified. None of the variables related to cost structure (that is, factor/input prices), diversification, or capacity displayed statistically significant associations with the initial certification decision even though means comparisons indicate differences between firms in all capacityrelated variables. When the timing of the initial adoption decision is considered, survival analysis results show that the number of product forms and membership and active involvement in industry associations are significant in addition to output price level and output size. 
Table 4 Results of the means comparison, logit, and survival analyses to explain initial adoption

\begin{tabular}{|c|c|c|c|c|c|}
\hline & \multirow{2}{*}{$\begin{array}{l}\text { Mean } \\
\text { All respondents }\end{array}$} & \multicolumn{2}{|c|}{ Means comparison } & \multirow{2}{*}{$\begin{array}{l}\text { Logit } \\
\text { model }^{a}\end{array}$} & \multirow{2}{*}{$\begin{array}{l}\text { Survival } \\
\text { analysis }^{b}\end{array}$} \\
\hline & & Certified once & No HACCP & & \\
\hline \multicolumn{6}{|l|}{ Incentive } \\
\hline Output price (US\$/kg) & 3.44 & 4.12 & 2.90 & $\begin{array}{l}0.32^{*} \\
(0.14)\end{array}$ & $\begin{array}{l}1.44^{* *} \\
(0.42)\end{array}$ \\
\hline EU-US price difference (US\$/kg) & -0.25 & -0.35 & 0.00 & $\begin{array}{l}-0.03 \\
(0.43)\end{array}$ & $\begin{array}{l}0.99 \\
(0.87)\end{array}$ \\
\hline EU-others price difference (US\$/kg) & 1.29 & 1.25 & 1.37 & $\begin{array}{l}-0.10 \\
(0.22)\end{array}$ & $\begin{array}{l}0.86 \\
(0.79)\end{array}$ \\
\hline Price of labor (US\$/day) & 2.93 & 2.95 & 2.87 & $\begin{array}{l}-0.03 \\
(0.23)\end{array}$ & $\begin{array}{l}1.03 \\
(0.97)\end{array}$ \\
\hline Price of materials $(\mathrm{US} \$ / \mathrm{kg})^{c}$ & 2.14 & 2.46 & $1.32^{*}$ & & \\
\hline Price of capital (US\$/unit of capital) & 0.19 & 0.21 & $0.14^{* *}$ & $\begin{array}{l}0.06 \\
(0.32)\end{array}$ & $\begin{array}{l}0.00 \\
(0.00)\end{array}$ \\
\hline Number of markets (number) & 3.00 & 4.00 & $1.00^{* * *}$ & $\begin{array}{l}0.02 \\
(0.11)\end{array}$ & $\begin{array}{l}1.11 \\
(0.87)\end{array}$ \\
\hline Number of product forms (number) & 2.00 & 2.00 & $3.00^{*}$ & $\begin{array}{l}-0.06 \\
(0.21)\end{array}$ & $\begin{array}{l}0.74^{*} \\
(0.32)\end{array}$ \\
\hline Output (000 tons/year) & 2.60 & 3.60 & $0.10^{* *}$ & $\begin{array}{l}0.09^{*} \\
(0.03)\end{array}$ & $\begin{array}{l}1.01^{* *} \\
(0.25)\end{array}$ \\
\hline \multicolumn{6}{|l|}{ Capacity } \\
\hline Difficulty in credit access (dummy $=0,1$ ) & 0.52 & 0.30 & $0.63^{* *}$ & $\begin{array}{l}0.04 \\
(0.04)\end{array}$ & $\begin{array}{l}0.81 \\
(0.96)\end{array}$ \\
\hline Years in business (number) & 10.40 & 11.25 & $7.00^{* * *}$ & $\begin{array}{l}0.01 \\
(0.02)\end{array}$ & $\begin{array}{l}0.96 \\
(1.01)\end{array}$ \\
\hline Active in associations (dummy $=0,1$ ) & 0.58 & 0.70 & $0.11^{* *}$ & $\begin{array}{l}0.07 \\
(0.05)\end{array}$ & $\begin{array}{l}2.08^{* * * *} \\
(0.59)\end{array}$ \\
\hline Number of associations (number) ${ }^{d}$ & 1.40 & 2.00 & $0.22^{* *}$ & & \\
\hline Age of plant facility (number) & 9.30 & 10.20 & 8.30 & $\begin{array}{l}0.02 \\
(0.03)\end{array}$ & $\begin{array}{l}0.96 \\
(0.87)\end{array}$ \\
\hline N & & & & 59 & 59 \\
\hline Pseudo $R$ squared & & & & 0.36 & \\
\hline$\%$ correctly predicted & & & & $60 \%$ & \\
\hline Schoenfeld residual & & & & & 0.32 \\
\hline
\end{tabular}

Source: various firm interviews conducted by the authors. The test of difference in means was performed using a means comparison test ( $t$ test) of unequal variances (using both Satterthwaite's and Welch's formulas) in the Stata program. Figures in parentheses are the standard errors

${ }^{* * *}$ Significant difference in averages at $<0.01$ level of significance; **at $<0.05$ level of significance; *at $<0.10$ level of significance

${ }^{\text {a } F i g u r e s ~ p r e s e n t e d ~ h e r e ~ a r e ~ m a r g i n a l ~ e f f e c t s ~}$

${ }^{\mathrm{b}}$ Figures presented here are hazard ratios

'Due to a multicollinearity problem from the high correlation between output price level and price of materials, we were able to use only one of these variables at a time in the models. However, the two models showed similar results. The one presented here is the one using output price level

"Due to a multicollinearity problem from the high correlation between "number of association memberships" and "being active in these associations," we were able to use only one of these variables at a time in the models. However, the two models showed similar results. The one presented here is the one using "being active in these associations"

A $\$ 1$ increase in the output price level is correlated with a $44 \%$ increase in the rate of initial adoption among firms, implying high sensitivity of the rate of initial adoption to changes in output price. A 1000-ton increase in annual output is associated with a $1 \%$ increase in the rate of initial adoption, suggesting that the larger the firm size, the larger the capacity of a firm to accommodate cost increases. We 
Table 5 Results of the means comparison, logit, and survival analyses to explain continued adoption (non-decertification)

\begin{tabular}{|c|c|c|c|c|}
\hline \multirow[t]{2}{*}{ Variable } & \multicolumn{2}{|c|}{ Means comparison } & \multirow{2}{*}{$\begin{array}{l}\text { Logit } \\
\text { model }^{a}\end{array}$} & \multirow{2}{*}{$\begin{array}{l}\text { Survival } \\
\text { analysis }\end{array}$} \\
\hline & Certified & $\overline{\text { Decertified }}$ & & \\
\hline \multicolumn{5}{|l|}{ Incentive } \\
\hline Output price level (US\$/kilogram [kg]) & 3.95 & 4.22 & $\begin{array}{l}1.28 \\
(0.87)\end{array}$ & $\begin{array}{l}0.30^{*} \\
(0.12)\end{array}$ \\
\hline EU-US price difference (US\$/kg) & -0.01 & $-0.94^{* * *}$ & $\begin{array}{l}-0.94^{* *} \\
(0.30)\end{array}$ & $\begin{array}{l}0.01^{* * *} \\
(0.00)\end{array}$ \\
\hline EU-others price difference (US\$/kg) & 1.35 & 1.09 & $\begin{array}{l}-0.65^{* *} \\
(0.21)\end{array}$ & $\begin{array}{l}1.09 \\
(0.89)\end{array}$ \\
\hline Price of labor (US\$/day) & 3.01 & 2.85 & $\begin{array}{l}0.33 \\
(0.22)\end{array}$ & $\begin{array}{l}0.37^{* * *} \\
(0.12)\end{array}$ \\
\hline Price of materials $(U S \$ / k g)^{c}$ & 2.25 & 2.73 & & \\
\hline Price of capital (US\$/kg) & 0.20 & 0.22 & $\begin{array}{l}-0.01 \\
(0.02)\end{array}$ & $\begin{array}{l}0.00 \\
(0.00)\end{array}$ \\
\hline Number of markets (number) & 3.00 & 3.00 & $\begin{array}{l}0.02 \\
(0.02)\end{array}$ & $\begin{array}{l}0.47^{* * *} \\
(0.13)\end{array}$ \\
\hline Number of product forms (number) & 2.00 & 2.00 & $\begin{array}{l}0.23 \\
(0.21)\end{array}$ & $\begin{array}{l}2.50^{* * *} \\
(0.69)\end{array}$ \\
\hline Output (000 tons/year) & 3.70 & 3.40 & $\begin{array}{l}-0.25 \\
(0.22)\end{array}$ & $\begin{array}{l}0.97 \\
(0.65)\end{array}$ \\
\hline \multicolumn{5}{|l|}{ Capacity } \\
\hline Difficulty in credit access (dummy $=0,1$ ) & 0.35 & 0.50 & $\begin{array}{l}0.42^{*} \\
(0.19)\end{array}$ & $\begin{array}{l}3.04^{* * *} \\
(1.01)\end{array}$ \\
\hline Years in business (number) & 10.50 & 11.30 & $\begin{array}{l}0.06 \\
(0.05)\end{array}$ & $\begin{array}{l}1.11 \\
(1.02)\end{array}$ \\
\hline Active in associations (dummy $=0,1$ ) & 0.80 & 0.60 & $\begin{array}{l}-0.01 \\
(0.01)\end{array}$ & $\begin{array}{l}0.30^{* * *} \\
(0.05)\end{array}$ \\
\hline Number of associations (number) ${ }^{d}$ & 2.00 & 2.00 & & \\
\hline Age of plant facility (number) & 9.00 & 11.20 & $\begin{array}{l}-0.07 \\
(0.06)\end{array}$ & $\begin{array}{l}0.81 \\
(0.67)\end{array}$ \\
\hline N & & & 59 & 59 \\
\hline Pseudo $R$ squared & & & 0.29 & \\
\hline$\%$ correctly predicted & & & $55 \%$ & \\
\hline Schoenfeld residual & & & & 0.29 \\
\hline
\end{tabular}

The test of difference in means was performed using a means comparison test ( $t$ test) of unequal variances (using both Satterthwaite's and Welch's formulas) in the Stata program. Figures in parentheses are standard errors

***Significant difference in averages at $<0.01$ level of significance; ${ }^{* *}$ at $<0.05$ level of significance; *at $<0.10$ level of significance ${ }^{a}$ Figures presented here are the marginal effects

${ }^{\mathrm{b}}$ Figures presented here are the hazard ratios

${ }^{\mathrm{C}}$ Due to a multicollinearity problem from the high correlation between output price level and price of materials, we were able to use only one of these variables at a time in the models. However, the two models showed similar results. The one presented here is the one using output price level

dDue to a multicollinearity problem from the high correlation between "number of association memberships" and "being active in these associations," we were able to use only one of these variables at a time in the models. However, the two models showed similar results. The one presented here is the one using "being active in these associations"

also used squared term of output size (in line with the findings of Rouviere (2016) showing an inverted U-shape effort-size relationship), but there is no evidence of such relationship in our dataset.

Adding an additional product form in the production line is correlated with a $26 \%$ decrease in the rate of initial adoption, perhaps because of costly processes to avoid cross-contamination. A firm active in trade or processor associations is twice as likely 
to adopt compared with an inactive firm, suggesting that associations may be sources of institutional pressure yet still provide needed capacity, information, technical support, and resources.

Overall results indicate that initial certification decisions are more strongly influenced by easily obtainable a priori indicators-namely, output prices, firm output, and to some extent association membership and product diversification. Less easily observable factors such as input cost structure and financial and operational capacity appear to have no influence on the initial adoption decision.

\section{Decertification decisions}

Explanatory variable mean values are statistically similar for both certified and decertified firms (Table 5) with the exception of the average EU-US price differential. Firms that remained certified (until 2006) reported no difference in prices received in the US and EU markets, but decertified firms (in 2006) reported receiving significantly lower prices from EU buyers compared with US buyers (by $\$ 0.94 / \mathrm{kg}$ on average) with the constant-hazard-rate assumption.

Logit model results indicate that price differentials across markets (especially between the EU and the USA) and access to credit are significant factors in the sustainability of HACCP certification among Philippine seafood processors. A \$1 per kilogram increase in EU prices, compared with US prices, is estimated to result in a 94\% decrease in the likelihood of being decertified, ${ }^{11}$ confirming high sensitivity of EU HACCP decertification to price differentials between the EU and US markets. Firms that received higher prices in the US market and sold a significant share of their output in the USA had no incentive to continue with EU HACCP certification. Logit model results also suggest that relatively lower EU prices versus prices in other markets (Japan, other non-US, and domestic) were negatively associated with continued certification. Factor prices were not significant in explaining decertification decisions when timing was not considered. Related to output price differences is the ratio of exports to EU to the USA and other markets. ${ }^{12}$ The higher the price difference between EU and US, the higher the ratio of exports to EU to the USA is. Certified firms' average share of exports to the EU (35\%) is statistically different from that of decertified firms (2\%). In contrast, the average share of exports to the USA was higher (and again statistically significant) for decertified firms (80\%), compared to certified firms (44\%). All 15 decertified firms reported no spillover effects-their US exports were not affected by EU HACCP decertification, since separate documentation was required and they had little incentive to maintain EU HACCP certification. For the certified firms, adopting the EU HACCP certification enabled them to comply with US HACCP requirements. For instance, four firms with no or very low EU exports still obtained EU HACCP certification and were able to maintain existing US markets. As a result, the EU's efforts to implement enhanced food safety controls may have contributed to improve system-wide efficiency and reduced costs of meeting the requirements of other export markets.

With respect to capacity, only access to credit had a statistically significant effect on continued certification decisions in the logit model: firms that reported difficulty accessing credit had a higher likelihood (42\%) of being decertified than firms reporting no difficulty. Capital requirements of food safety systems increase the demand for scarce 
funds, and public-sector credit support may be needed to jump-start and sustain food safety systems.

When the constant-hazard-rate assumption is relaxed (that is, survival analysis), the rate of decertification is significantly affected not only by EU-US price differentials but also by other incentive- and capacity-related factors such as output price level, input prices, number of markets, number of product forms, access to credit, and membership and active involvement in associations. Reported hazard ratio estimates suggest that a $\$ 1$ increase in the difference between EU and US prices is associated with a $99 \%$ decrease in the rate of decertification. With an average EU-US price differential in $2004-2008$ of $-\$ 0.25 / \mathrm{kg}$, a dollar increase will make EU prices four times more attractive than US prices and will likely eliminate almost all EU HACCP decertifications by firms. Results suggest that firms choose their certification strategies depending on their target market. In our sample, firms that exported mainly to the EU were less likely to decertify from EU HACCP, whereas firms that exported mainly to the USA and other markets were more likely to decertify. Hence, HACCP capacity building appears to be tailored to requirements of the importing nations.

Similarly a $\$ 1$ increase in the output price level is associated with a $70 \%$ reduction in the rate of decertification, suggesting very high sensitivity of the rate of decertification to changes in price level. An increase in the number of product forms by one is associated with a 2.5 times increase in the rate of decertification (i.e., firms handling multiple product forms were highly likely to decertify). In contrast, an additional market destination is associated with a 53\% decrease in the rate of decertification, indicating that reputation achieved through EU HACCP certification was important in continued certification for firms selling in a number of markets.

Factor prices were also significant when time was considered; a $\$ 1$ increase in the price of labor is associated with a $63 \%$ decrease in the rate of decertification. Although this result appears to be inconsistent with the initial hypothesis that higher wage rates will create incentives for decertification because of the additional labor involved with maintaining safe practices, discussions with respondents suggest that higher wage rates created incentives for the firms to seek higher prices through HACCP certification as a competitive strategy because higher local wage rates made them uncompetitive in domestic markets. Firms that reported difficulty in accessing credit had a rate of decertification three times higher than those that reported no difficulty. These results suggest that easy access to credit is a critical factor driving both initial and sustained certification.

A firm that is active in an association has a $70 \%$ lower rate of decertification than a firm that is not active. Institutional pressures imposed through association membership and the potential preferential access to resources because of active participation play important roles in influencing continued certification. Building institutional pressures and collective capacity through industry associations can help promote early adoption as well as continued certification. Such associations can provide a venue to mobilize resources and share expertise and relevant information about food safety systems and market opportunities. Shared information through industry associations can reduce erroneous decisions arising from managerial hubris.

Scale economies did not appear to play a significant role in the decertification decision, likely because firms without adequate scale economies were filtered out in the 
initial certification decision. Even though improving food safety is paramount across all firm types and firm sizes, some firms may need different forms of incentives and capacity building on a more sustained basis.

\section{Conclusions}

Lack of knowledge about the sustainability of food safety certification systems constitutes a major gap in our understanding of food policy and regulation. Relaxing the constant-hazard-rate assumption using survival analysis techniques reveals the significant influence of additional factors on the conditional decisions. Differences between survival and logit model estimates for both initial certification and subsequent decertification decisions suggest that assuming constant hazard rates may lead to potentially misleading results and misestimation of the influence of other relevant drivers.

The initial decision to certify appears to be influenced significantly by scale economies and easily observable information such as output prices, access to credit, and institutional pressures from association membership. Other incentive- and capacityrelated factors do not appear to have a significant influence.

After certification, a firm's decision to continue or discontinue certification at a point in time will be influenced by the same set of incentive- and capacity-related factors, but with the availability of additional information concerning realized costs and benefits. As a result decertification decisions appear to be significantly affected by a larger number of revenue, cost, and nonfinancial factors (that is, output price differentials, product and market diversification, input prices, and institutional factors). Although logit model results suggest that price differences between the EU, USA, and other markets and credit availability are the main drivers of the decertification decision, estimates using survival analysis techniques reveal the significant influence of additional factors, including the extent of market and product diversification, institutional pressures, and labor costs (wages).

Social capital is proven to be a significant factor in explaining both initial adoption and continued certification, which is consistent in the literature. Firm or production size is significant in explaining initial certification but not continued certification, and our findings contrast that of Rouviere (2016) showing inverted U-shape effort-size relationship.

Managerial hubris, likely in the absence of adequate information, may have played a significant role in initial certification decisions, but decertification decisions were based on more informed cost and benefit information. The results support our hypothesis that compared with initial certification, decertification decisions were better informed, calculated business decisions. For food processing firms, the results suggest the need for more careful estimation of benefits and costs and avoidance of managerial debris in order minimize any adverse firm performance and sunk costs associated with certification. For policymakers and the development community, the results suggest that an increased emphasis on policy measures aimed at discouraging decertification and actions to provide greater sustained incentives for food safety systems, versus a focus limited to capacity building to achieve initial certification, may be necessary to sustain food safety initiatives such as HACCP.

We present in the paper a rigorous quantitative model that explains the dynamics of food safety certification, using the HACCP case in the Philippines. However, our paper is not without limitations. First, the sample for this study is drawn from a single country, and the 
analysis is specific to EU HACCP certification. Although we are confident that the sample is representative of the seafood-processing industry in the Philippines, it may not represent the seafood industry in general. It does allow us to control for factors that vary between countries and between certification programs. We control for potential variation in the national-level factors by using a sample of firms drawn from a single country (Philippines) and assuming that the national capacity is unchanged during the study period. As a result, the focus is on firm-level drivers of certification and decertification decisions.

Second, the main data analyzed are from 2004 to 2005, which may seem outdated. Nevertheless, since the focus is on illustrating the use of a methodological novelty in studying food safety, using data from 2005 is still informative and insightful. Moreover, in 2011 and in 2014, a random visit to 10 of the sample firms revealed that they face the same HACCP regulation in the EU markets, and the other markets like the USA are also becoming more stringent. The general decision frame shown in Fig. 2 and the choice model in Eq. 7 are proven to be still valid. Moreover, a recent review of fisheries and seafood regulations in the Philippines and in the EU reveals that HACCP is the major food system being implemented but with added measures such as Rapid Alert System for Food and Feed (RASFF).

The major change that may affect the interpretation and implications of our results is the intensity and frequency of training and capacity building received since 2005. Major efforts have been exerted by the EU to build capacity of the competent authorities of the exporting countries to review and implement HACCP certification and RASFF. Given more knowledge and resources flowing, the importance of social capital may be less significant in more recent years. For further research, this paper can be extended by using more recent data and by comparing with other countries and other food certification systems including that of GlobalGAP, which focuses on the agricultural and aquaculture farm level.

\section{Endnotes}

${ }^{1}$ This model is also used by Antle (2000) as the starting point in estimating the cost of food safety regulation in the US meat industry.

${ }^{2}$ Social capital is defined here as a communal property involving civic engagement, associational membership, high trust, reliability, and reciprocity in social networks" (Cooke and Wills 1999).

${ }^{3}$ A firm's EU HACCP certification was reported to be accepted for entry to the US market, but the converse was not true. At the time of data collection, firms interviewed suggest a less systematic implementation of US certification requirements, ranging from simply faxing a HACCP plan to rigorous third-party certification.

${ }^{4}$ The sample was drawn from 185 firms in the three regions with a 2005 license to operate issued by the Philippine Bureau of Food and Drugs (BFAD). The initial population for the primary data collection consisted of a comprehensive list of 500 seafood processors from the Philippine Bureau of Food and Drugs (BFAD, 2005). Of these, 248 were classified as very tiny cottage operations producing dried small fish, fish paste and sauce, etc., targeted for low-income domestic markets and often not considered "seafood." An additional 67 firms on the initial list were no longer operating, leaving 185 
firms as the relevant population. Cluster sampling was used to select 136 firms based on the geographical concentration of seafood processing in three regions (Luzon, Visayas, and Mindanao). Operations or production managers (or assistant manager or HACCP team leader in cases where the manager was not available) of these 136 firms were contacted by phone, seeking participation in the study. Interviews were conducted with a total of 59 firms, which were willing to be interviewed and which accounted for $32 \%$ of the population of seafood-processing firms and $67 \%$ of the volume and value of exports in 2004. Discussions with key government and industry informants confirm that the firms included are representative of other firms in the three cluster areas.

${ }^{5}$ Firm size is based on the Philippine Department of Trade and Industry (DTI)'s classification: cottage or micro firms-less than 10 full-time equivalent employees; small firms -10 to 99 employees; medium firms-100 to 299 employees; and large firms $\rightarrow 300$ employees. Due to observed heterogeneity among firms categorized as small, we further segregate small firms into very small firms with 10 to 32 employees and small firms with 33 to 99 employees. A means comparison suggests that sample firms are not statistically different from industry aggregates. The expert opinion of officials from BFAD, which inspects and issues licenses to operate, confirms that the sample is representative of the population.

${ }^{6}$ A total of 38, 96, and 36 firms were EU HACCP certified in 2000, 2004, and 2005, respectively. The number stayed the same in 2014 when the firms were revisited. The exact number of US-certified firms is less well known, but at least 30 firms were listed as certified in 2005.

${ }^{7}$ The group of firms without EU HACCP certification includes some that may have received other types of food safety certification.

${ }^{8}$ There are several parametric models to be used based on the distribution of the hazard/risk: exponential, Weibull, Gompertz, log-logistic, log-normal, and generalized gamma models. The common approach in selecting among such approaches is to use the Akaike information criterion (AIC). Akaike (1974) proposed penalizing each log likelihood to reflect the number of parameters being estimated in a particular model and then comparing them. AIC is defined as $A I C=-2(\log$ likelihood $)+2(c+p+1)$, where $c$ is the number of explanatory variables and $p$ is the number of model-specific ancillary parameters, that is, two ancillary parameters for generalized gamma and one for the other models. The preferred model has the smallest AIC value.

${ }^{9}$ This is often preferred especially in applications to social sciences, in which there is not enough theory to make a strong case to assume a constant, increasing, or decreasing baseline hazard.

${ }^{10}$ The hazard ratio has a similar interpretation as the odds, or likelihood, ratio in logit models, and the only difference is that the ratio is the rate for survival analysis.

${ }^{11}$ This is computed by dividing the coefficient by 100 and then recomputing the odds ratio (marginal effect) (see Hosmer and Stanley 1999).

${ }^{12}$ We opted to use prices instead of export quantity or ratios for two reasons. First, due to high correlation with price differentials and ratio of exports between EU and USA, we used these variables alternatively in the models. Second, Philippines is a price taker, and prices faced by seafood exporters are exogenous to the model, while export quantity or ratios are endogenous to the HACCP certification models, where there is likely to be a reverse causality. 


\section{Acknowledgements}

We are grateful for research funding from the Michigan State University Graduate School and Institute of International Agriculture; support from the Philippine Institute for Development Studies and from Ms. Ching Baltazar, Bureau of Fisheries and Aquatic Resources, Philippines; and the research assistance of Gee Lavina-Moral and Emma Cinco. Thanks go also to the Philippine government officials and private individuals who shared data, information, and experiences and whose active and dynamic participation in the interviews gave rich resources and insights to this paper.

\section{Authors' contributions}

CR conducted the interviews and fieldwork, analyzed the initial results, and drafted the earlier versions. ST provided inputs on the interview questionnaire, discussion of results, and literature review, and she edited the paper. SJ initiated the survival analysis, contributed to the framing of the paper, and provided inputs to the discussion section. All authors read and approved the final manuscript.

\section{Authors' information}

$C R$ is an agricultural economist whose research focuses on mixed quantitative and qualitative analysis of policies, institutions and technologies affecting innovation, productivity growth, and agricultural development. She has published in top food policy and economics journals and has numerous published working papers and policy notes on food safety, agricultural innovation, seed, and extension systems and impact assessment of public investments and agricultural programs focusing on Africa and Asia. ST is currently an economist at the Economic Research Services of US Department of Agriculture. Her research focuses on agricultural markets, trade and food safety. Previously, she was an associate professor at the Department of Agricultural, Food, and Resource Economics of Michigan State University, East Lansing, Michigan. SJ is currently an associate professor in the Department of Agricultural, Food, and Resource Economics of Michigan State University, East Lansing, Michigan. His research focuses on environmental economics and food regulation. He has published numerous articles and papers in various high-ranked journals.

\section{Competing interests}

The authors declare that they have no competing interests.

\section{Publisher's Note}

Springer Nature remains neutral with regard to jurisdictional claims in published maps and institutional affiliations.

\section{Author details}

${ }^{1}$ Development Strategy and Governance Division of International Food Policy Research Institute, Washington, DC, USA. ${ }^{2}$ Economic Research Service of US Department of Agriculture, Washington, DC, USA. ${ }^{3}$ Department of Agricultural Food and Resource Economics of Michigan State University, East Lansing, MI, USA.

Received: 29 February 2016 Accepted: 23 May 2017

Published online: 08 June 2017

\section{References}

Abdulai A, Huffman WE (2005) The diffusion of new agricultural technologies: the case of crossbred-cow technology in Tanzania. Am J Agric Econ 87(3):645-659

Akaike H (1974) A new look at the statistical Model Identification. IEEE Trans Automatic Control AC-19:716-723

Anders S, Caswell J (2009) Standards as barriers versus standards as catalysts: assessing the impact of HACCP implementation on US seafood imports. Am J Agric Econ 91:310-321

Bansal P, Clelland I (2004) Talking trash: legitimacy, impression management, and unsystematic risk in the context of the natural environment. Acad Manag J 47(1):93-105

Barros CP, Machado LP (2010) The length of stay in tourism. Ann Tour Res 37(3):692-706

Clarke TG, Bradburn MJ, Love SB, Altman DG (2003) Survival analysis part I: basic concepts and first analyses. Br J Cancer 89:232-238

Cooke P, Wills D (1999) Small firms, social capital and the enhancement of business performance through innovation programmes. Small Bus Econ 13(3):219-234

Cox DR (1972) Regression models and life tables. Journal of the Royal Statistical Society. Series B Statistical Methodol 34(2):187-220

Curzi D, Raimondi V, Olper A (2015) Quality upgrading, competition and trade policy: evidence from the agri-food sector. Eur Rev Agric Econ 42(2):239-267

Debon A, Carrion A, Solano H (2010) Comparing risk of failure models in water supply networks using ROC curves. Reliab Eng Syst Saf 95:43-48

Dimara E, Skuras D, Tsekouras K, Tzelepis D (2008) Productive efficiency and firm exit in the food sector. Food Policy 33:185-196

Dzwolak W (2014) HACCP in small food businesses-the Polish experience. Food Control 36(1):132-137

Fotopoulos C, Kafetzopoulos D (2011) Critical factors for effective implementation of the HACCP system: a Pareto analysis. Br Food J 113(5):578-597

Green M, Kane K (2014) The effective enforcement of HACCP based food safety management systems in the UK. Food Control 37:257-262

Hammoudi A, Hoffmann R, Surry Y (2009) Food safety standards and agri-food supply chains: an introductory overview. Eur Rev Agric Econ 36(4):469-478

Handschuch C, Wollini M, Villalobos P (2013) Adoption of food safety and quality standards among Chilean raspberry producers—do smallholders benefit? Food Policy 40:64-73

Henson S, Caswell J (1999) Food safety regulation: an overview of contemporary issues. Food Policy 24(6):589-603 
Henson S, Holt G (2000) Exploring incentives for the adoption of food safety controls: HACCP implementation in the UK dairy sector. Rev Agric Econ 22:407-420

Herath D, Hassan Z, Henson S (2007) Adoption of food safety and quality controls: do firm characteristics matter? Evidence from the Canadian food processing sector. Can J Agric Econ 55(3):299-314

Hosmer D Jr, Stanley S (1999) Applied Survival Analysis: Regression Modeling of Time to Event Data. Wiley, New York Israel D (2014) The potential impacts of a free trade agreement with the European Union on the Philippine fisheries sector. PIDS Discussion Paper Series 2014-03, Makati, Philippines

Jarosz L (2000) Understanding agri-food networks as social relations. Agric Hum Values. 17(3):279-283

Jiang F, Stone GR, Sun J, Zhang M (2011) Managerial hubris, firm expansion, and firm performance: evidence from China. Social Science Journal 48(3):489-499

Joshi S, Krishnan R, Lave L (2001) Estimating the hidden costs of environmental regulation. Account Rev 76:171-198

Kurian AW, Sigal BM, Plevritis SK (2009) Survival analysis of cancer risk reduction strategies for BRCA1/2 mutation carriers. J Clin Oncol 28(2):222-231

Madan RA, Gulley JL, Schlom J, Steinberg S, Liewehr D, Dahut WL, Arlen PM (2008) Analysis of overall survival in patients with nonmetastatic castration-resistant prostate cancer treated with vaccine, nilutamide, and combination therapy. Clin Cancer Res 14:4526-4531

Maldonado-Siman E, Bai L, Ramirex-Valverde R, Gong S, Rodriques-de Lara R (2014) Comparison of implementing HACCP systems of exporter Mexican and Chinese meat enterprises. Food Control 38:109-115

Mattox JR II, Jinkerson DL (2005) Using survival analysis to demonstrate the effects of training on employee retention. Eval Program Plann 28:423-430

Menard SW (2008) Handbook of longitudinal research: design, measurement, and analysis. Elsevier, San Diego

Menard C, Valceschini E (2005) New institutions for governing the agri-food industry. Eur Rev Agric Econ 32(3):421-440

Meyer JW, Rowan B (1977) Institutionalized organizations: formal structure as myth and ceremony. Am J Sociol 83:340-363

Minor T, Parrett M (2017) The economic impact of the Food and Drug Administration's Final Juice HACCP Rule. Food Policy 68:206-213

Morgenstern R, Pizer W, Shih J (2001) The cost of environmental protection. Rev Econ Stat 83(4):732-738

Ollinger M, MacDonald J, Madison M (2005) Technological change and economies of scale in U.S. poultry processing. Am J Agric Econ 87(1):116-129

Olmos MF (2010) An Investigation of factors that influence the survival of contracts in the DOCa Rioja wine Industry. Appl Econ Perspect Policy 32(2):298-318

Panisello P, Quantick P (2001) Technical barriers to Hazard Analysis Critical Control Points (HACCP). Food Control 12(3):165-173

Ragasa C, Thornsbury S, Bernsten R (2011a) Delisting from EU HACCP certification: analysis of the Philippine seafood processing industry. Food Policy 36:694-704

Ragasa C, Thornsbury S, Joshi S (2011 b) Are food certification costs misestimated? Exporter-perspective on the European standard. J Agric Econ 62(3):669-689

Roll R (1986) The hubris hypothesis of corporate takeovers. J Bus 59(2):197-216

Rosen S (1974) Hedonic prices and implicit markets: product differentiation in pure competition. J Polit Econ 82:34-55

Roszbach K (2004) Bank lending policy, credit scoring, and the survival of loans. Rev Econ Stat 86(4):946-958

Rouviere E (2016) Small is beautiful: firm size, prevention and food safety. Food Policy 63:12-22

Russo A, Perrini F (2010) Investigating stakeholder theory and social capital: CSR in large firms and SMEs. J Bus Ethics 91(2):207-221

Scott WR (2001) Institutions and organizations, 2nd edn. Sage, Thousand Oaks, CA, US

Singer JD, Willett JB (2003) Applied longitudinal data analysis: modeling change and event occurrence. Oxford University Press, Oxford, England

Soderbom M, Eal F, Harding A (2006) The determinants of survival among African manufacturing firms. Econ Dev Cult Change 54(3):534-555

Song H-R, Lawson A (2009) Space-time Bayesian survival modeling of chronic wasting disease in deer. Prev Vet Med 91:46-54

Spitale A, Mazzola P, Soldini D, Mazzucchelli L, Bordoni A (2009) Breast cancer classification according to immunohistochemical markers: clinicopathologic features and short-term survival analysis in a population-based study from the South of Switzerland. Ann Oncol 20(4):628-635

Sporleder T, Moss LA (2002) Knowledge Management Frontier in the Global Food System: Network Embeddedness and Social Capital. Am J Agric Econ 84 (5): 1345-1352

Stock JH, Watson W (2003) Introduction to Econometrics. Addison-Wesley, Boston, MA

Taylor E, Taylor J (2004) Using qualitative psychology to investigate HACCP implementation barriers. Int J Environ Health Res 14(1):53-63

Tiller K, Feleke S, Starnes J (2009) A discrete-time hazard analysis of the exit of burley tobacco growers in Tennessee, North Carolina, and Virginia. Agric Econ 41(5):397-408

Trienekens J, Wognum P, Beulens A, vander Vorst J (2012) Transparency in complex dynamic food supply chains. Adv Eng Inform 26(1): 55-65

Unnevehr L (2015) Food safety in developing countries: moving beyond exports. Global Food Secur 4:24-29

Verbeek M (2004) A guide to modern econometrics, 2nd edn. John Wiley, Chichester

Wallace C, Holyoak L, Powell S, Dykes F (2014) HACCP—-the difficulty with hazard analysis. Food Control 35(1):233-240

Wooldridge J (2003) Introductory econometrics. South-Western, Thomson Learning, Mason, OH, US

Ziggers GW, Trienekens J (1999) Quality assurance in food and agribusiness supply chains: Developing successful partnerships. Int J Prod Econ 60-61(20): 271-279 